\title{
Moringa oleifera as Sustainable Source for Energetic Biomass
}

\author{
Francisco Sávio Gomes Pereira ${ }^{1,2}$, Ana Maria Ribeiro Bastos da Silva ${ }^{3}$, Chesque Cavassano Galvão ${ }^{3}$, Valmir \\ Felix de Lima $^{3}$, Lucas Gico Lima de Assunção Montenegro ${ }^{3}$, Nelson Medeiros de Lima-Filho ${ }^{3}$, Valdinete Lins da \\ Silva ${ }^{2,3}$ \\ ${ }^{1}$ Federal Institute of Education, Science and Technology of Pernambuco - IFPE, Campus Recife, Brazil \\ ${ }^{2}$ Federal University of Pernambuco-UFPE. Center of Exact Sciences and Nature. Department of Fundamental \\ Chemistry, Recife, Brazil \\ ${ }^{3}$ Federal University of Pernambuco-UFPE. Center of Technology and Geosciences. Department of Chemical \\ Engineering. Recife, Brazil \\ Correspondence: Francisco Sávio Gomes Pereira, Federal Institute of Education, Science and Technology \\ Pernambuco-IFPE, Campus Recife, Zip Code: 50740-540, PE, Brazil, E-mail: cientista.francisco@yahoo.com.br
}

Received: October 8, 2015 Accepted: October 10, 2015 Online Published: October 20, 2015

doi:10.5539/ijc.v7n2p177 URL: http://dx.doi.org/10.5539/ijc.v7n2p177

\begin{abstract}
This work investigated the biomasses (seeds, seed husks, oilseed grains, crude and purified oils, cakes by pressing and by hexane extraction and methyl biodiesel the oil) of Moringa oleifera Lamarck, starting with its seedpods (ripe and dry fruits) in energetic application. The oil obtained from the grains by mechanical pressing had an average yield of $11.36 \%$ and of $36.48 \%$ by hexane extraction. The moringa biomasses presented calorific values between 15.87 and $37.53 \mathrm{MJ} / \mathrm{kg}$, being suitable as renewable biofuels. The mixed crude oil (1:4) was refined in four steps: degumming, neutralization, washing and drying. The crude and refined oils were characterised by acidity index, peroxide index, water content, turbidity, specific mass, kinematic viscosity, power calorific higher, calorific power below and ash content. The crude oils by pressing and by solvent extraction were characterised through of the saponification index and iodine value. The purified biodiesel presented specific mass of $889 \mathrm{~kg} / \mathrm{m} 3(20 \mathrm{oC})$, kinematic viscosity of $5.5 \mathrm{~m} 2 / \mathrm{s}(40 \mathrm{oC})$, content of ester of $86.2 \%$ and $98.23 \%$ (in microscale, ratifying the viability of the method), acidity index of $0.43 \mathrm{mg} \mathrm{KOH} / \mathrm{g}$ and water content of $615.8 \mathrm{mg} / \mathrm{kg}$. The solid moringa biomasses (seeds, cakes (or pies) and the seed husks) show high potential for the production of briquettes or ecological firewood due to its content energy expressed as lower calorific value (between 15.87 and $23.31 \mathrm{MJ} / \mathrm{kg}$ ) and simple and accessible technological production. The results show that moringa is an easily exploitable plant in sustainable energy, especially from its seedpods and seeds.
\end{abstract}

Keywords: alkaline transesterification, briquettes, biomass, moringa biodiesel, moringa oil, oil analysis

\section{Introduction}

\subsection{Biomasses and Applied Technologies Used}

Broadly speaking, the term biomass refers to any type of renewable vegetable or animal organic material. These materials have in common the direct or indirect origin of the photosynthesis process, and are therefore considered renewable. Biofuels are produced through the use or conversion of biomass, and contain dendrofuels (fuels derived from wood), agrofuels (fuels derived from agricultural waste) and urban waste (Nogueira \& Lora, 2003).

Biomass energy is presented in its chemical form and can be stored and generate energy, including steam generation and other uses (Nogueira \& Lora, 2003). Furthermore, photosynthesis creates biomass that can be converted into renewable bioenergy, using the solar energy stored. Conversion of biomass into biofuel can be achieved by different methods, the main ones being classified in three groups: physical (densification or drying, particle size reduction and mechanical pressing), thermochemical (pyrolysis, gasification, liquefaction and combustion), physicochemical (transesterification, catalysis, etc.) and biological (fermentation and anaerobic digestion) (Bussi, Castigliori, \& Tancredi, 2004).

\subsection{Analytical Parameters that Characterise Biomass}

Humidity (\%), ash content (\%) and lower calorific value $(\mathrm{MJ} / \mathrm{kg})$ are the most used analytical parameters to 
define biomass energy. In a more simple way, the lower calorific value (LCV) can be considered as the net calorific value used in fuels, while the higher calorific value (HCV) is around 5 to $10 \%$ higher and usually determined in the laboratory (Nogueira \& Lora, 2003).

Air-dried firewood naturally displays between 23 to $38 \%$ humidity, and between 0.29 and $0.79 \%$ of ash content, as well as a lower calorific value varying from 10.8 and $13.8 \mathrm{MJ} / \mathrm{kg}$. The sugarcane bagasse, in its turn, presents $50 \%$ humidity, $11.27 \%$ of ash content and lower calorific value of $8.4 \mathrm{MJ} / \mathrm{kg}$ (Nogueira \& Lora, 2003).

\subsection{Moringa oleifera and Its Energetic Potential}

The origin of Moringa oleifera is mostly unknown, being cultivated since ancient times; it supposedly originated in Agra and Oudh, in India, south of the Himalayas (Foidl, Makkar, \& Becker, 2001). It is part of the Moringaceae family, of single genus, being one of the 13 species known (Fahey, 2005). It can be cultivated in arid, semiarid and warm areas, with temperatures between 25 and $35{ }^{\circ} \mathrm{C}$, but can temporarily tolerate up until 48 ${ }^{\circ} \mathrm{C}$ as well as weak frost conditions in subtropical areas (HDRA, 2002). It is tolerant to drought and grows with annual precipitation between 250 and $3,000 \mathrm{~mm}$ and in altitudes below $600 \mathrm{~m}$. The moringa can be cultivated in soils with $\mathrm{pH}$ between 5.0 and 9.0, but it develops better in neutral and well-drained soils (Crosby, 2007). It also adapts better to sandy-clay, well-drained soils but it can grow in clay soil without stagnant water. The soil does not necessarily need to be fertile, with the crop developing in poor soil as well, starting to flower 8 months after being planted and to produce fruits within 15 months (HDRA, 2002).

In the energetic aspect, the moringa can be used in several ways: in production the biogas, of bioethanol, biodiesel or of briquettes.

\subsubsection{Biogas}

Foidl et al. (2001) performed experiments with biogas production from plant material (biomass) of the moringa. Moringa crops (approximately 30 days old) were crushed together with water. The fibre was filtrated through a 5 $\mathrm{mm}$ sieve and the liquid fraction produced was then added to a biogas reactor. An average of $5.7 \mathrm{~g}$ of volatile solids were added to the reactor, with gas production of $580 \mathrm{~L} / \mathrm{kg}$. The average level of methane in the gas was of $81 \%$. Based on experiments, it was estimated that more than $4,400 \mathrm{~m}^{3}$ of methane could be produced by hectare/year of moringa. This counts as up to twice more methane that could be produced by hectare/year from beetroot leaves, a common material for biogas production. Further research is recommended to examine this potential use of moringa.

\subsubsection{Bioethanol}

The sugar and starch found in the Moringa oleifera plant are extracted by mechanical crushing, wash, concentration and flocculation; and it is of great potential for the industrial alcohol production. According to the data mentioned in scientific literature, sugar and starch are concentrated in the moringa leaves in content of 10 and $8 \%$, respectively. The production of $10 \mathrm{MW}$ of electric energy, $80 \mathrm{t}$ of proteic material and 16,000 litres of alcohol per day requires an irrigated cropping system of 1,500 ha of moringa. In 1 ha of sugarcane, $630 \mathrm{~L} / \mathrm{year}$ of alcohol can be produced from the molasses obtained in the sugarcane production, while the same area with Moringa oleifera plantation can produce 8,400 L/year (Foidl et al., 2001).

\subsubsection{Biodiesel}

Moringa oleifera has it taken of great importance for biodiesel production, being one vegetal specie with the high content of oil (approximately 35\%). Its cultivation has an approximately $2,500 \mathrm{~kg} / \mathrm{ha}$ yield, with 1,478 L/ha of oil and a conversion factor of biodiesel of 0.96 , with estimate the production of $1,419 \mathrm{~L} / \mathrm{ha}$ of biodiesel. In one hectare of land, between 700 and 1,100 Moringa oleifera trees can be planted, which start to produce fruits within 12 months (Foidl et al., 2001). Furthermore, the biodiesel produced from the moringa oilseeds can reach in the viscosity and specific mass within the parameters required by the National Petroleum, Natural Gas and Biofuels Agency - the ANP, Brazil.

\subsubsection{Briquettes}

Briquette is an ecological firewood (recycled), result of a drying and sawdust pressing process of the most diverse wood types and forest and industrial residues. Briquettes are adequate to be used in industrial boilers and also as a replacement of the usual firewood, of fuel oil and derived from natural gas. The biomass briquette uses agro-industrial wastes. Briquetting is a process of compacting agricultural and industrial residues and it can be divided into four steps: Preparation (the raw material is reduced in size and the type of equipment to be used is determined), Mixing the raw material (the binder must be uniformly distributed over all the briquette material's surface), Thermal Treatment (to avoid rupture due to thermal shock and storage of the briquettes), 
Pre-compaction (to reduce the volume and load the material up until the chamber of the extruder), Compaction (the feedstock is compressed until its extrusion) (Brasil Biomassa e Energia Renovável [BBER], 2015).

\subsection{Biodiesel (vegetable oil as an indirect biomass for energetic use)}

The National Programme of Production and Use of Biodiesel (PNPB) - Brazil, conceptualizes biodiesel as: "A Fuel obtained from mixtures, in different proportions of diesel and esters of vegetable oils". Technically speaking, biodiesel is defined as an alkyl ester of fatty acids, obtained by the transesterification of a triglyceride (oil or fat saponifiable, vegetable or animal), with an alcohol (commonly methanol or ethanol). Transesterification is the chemical reaction of a vegetable oil with an alcohol, which can be ethanol or methanol, in the presence of a catalyst (acid or base). Generally for transesterification reaction either acid or base catalyst can be used. The result is a methyl or ethyl ester (biodiesel), according to the alcohol used, and glycerine or glycerol (Ramos, Silva, Mangrich, \& Cordeiro, 2011).

In Brazil, the feedstocks used in the biodiesel production are: soybean oil, beef tallow and cottonseed oil. For biodiesel production, it is recommended the use of an oil with low levels of acidity (lower than $0.5 \%$ in free fatty acids to reduce the production of soap) and water-free (which contributes to the formation of free fatty acids, unwanted in the transesterification reaction), requiring a more difficult process of purification (Ramos et al., 2011). Therefore, moringa oil is of great potential for biodiesel production.

As energy is essential for human survival, the Moringa oleifera Lamarck (Figure 1a) is presented as a sustainable energetic alternative and, in this study, the potential of the biomasses produced from the seeds of this plant (oil, cakes and seed coats) and of the biodiesel obtained from the oil in the homogeneous alkaline transesterification reaction is investigated.

\section{Material and Methods}

\subsection{Harvesting, Extraction, Purification and Converting the Oil into Biodiesel}

Ripe moringa pods (Figure 1b), between 30 and $40 \mathrm{~cm}$, were harvested between April and May 2014 in Recife, in the State of Pernambuco, Brazil. The suitable pods produced seeds that generated oilseed grains and husks (Figure 1c). The oilseed grains produced the cake (or pie) and crude oil by pressing (Figure 1d).

The cold pressed grains (pressing at $10 \mathrm{t}$ or $412.5 \mathrm{~kg} / \mathrm{cm}^{2}$ for 5 mins., in manual hydraulic press Shulz, model 15 Ton) and by hexane extraction in Soxhlet (crushed and screened grains with extractive cycle for 4 hours) produced oils with slightly different sensory characteristics (Figure 1e).

The mixed crude oil (by pressing and by solvent extraction, 1:4 proportion) was degummed (20\% of deionized water in relation to the oil/ temperature of $60{ }^{\circ} \mathrm{C}$ in thermostatically-controlled water bath/mechanic agitation of $500 \mathrm{rpm}$ for $15 \mathrm{mins}$./ centrifugation at 5,000 rpm for 15 mins.), neutralized the cold $(\mathrm{NaOH} 5 \%$, calculated according the acidity of oil/ mechanic agitation of $500 \mathrm{rpm}$ for $15 \mathrm{mins}$./ centrifugation at 5,000 rpm for 15 mins.), 3 times washed (deionized water/ treated oil in 1:1 proportion/ agitation of $1,000 \mathrm{rpm}$ for $30 \mathrm{mins} . /$ decantation for 2 hours) and dried (heated to $100{ }^{\circ} \mathrm{C}$ for 60 mins. with intermittent agitation every 5 mins.).

The purified oil (Figure 1f) was converted into methyl biodiesel by alkaline transesterification with potassium hydroxide as a catalyst $\left(1: 6\right.$ molar ratio, oil/methanol, $0.8 \%$ of catalyst, at $60{ }^{\circ} \mathrm{C}$ and 60 mins. of mechanic agitation of $300 \mathrm{rpm}$ ) in a single trial to calculate the yield in the light phase (impure biodiesel) and heavy liquid phase (impure glycerine) (Figure 1g). The biodiesel (light phase) was purified using a phosphoric acid solution at $2 \%$, and washes with distilled water (with $\mathrm{pH}$ monitoring in produced wastewaters until neutral condition) and dried by thermostatically-controlled water bath heated to $70{ }^{\circ} \mathrm{C}$ for 30 mins. After that, anhydrous sodium sulphate was added in the dry biodiesel, homogenized for 5 mins., and vacuum filtered to remove remaining water. The purified biodiesel (Figure 1h) was analysed in terms of ester contents to determine its purity and production yield.

The samples of this study (Figure 2) were: seeds, oilseed grains, cakes (or pies), oils, seed husks and biodiesel, and were measured humidity content, ash content and power calorific higher. 

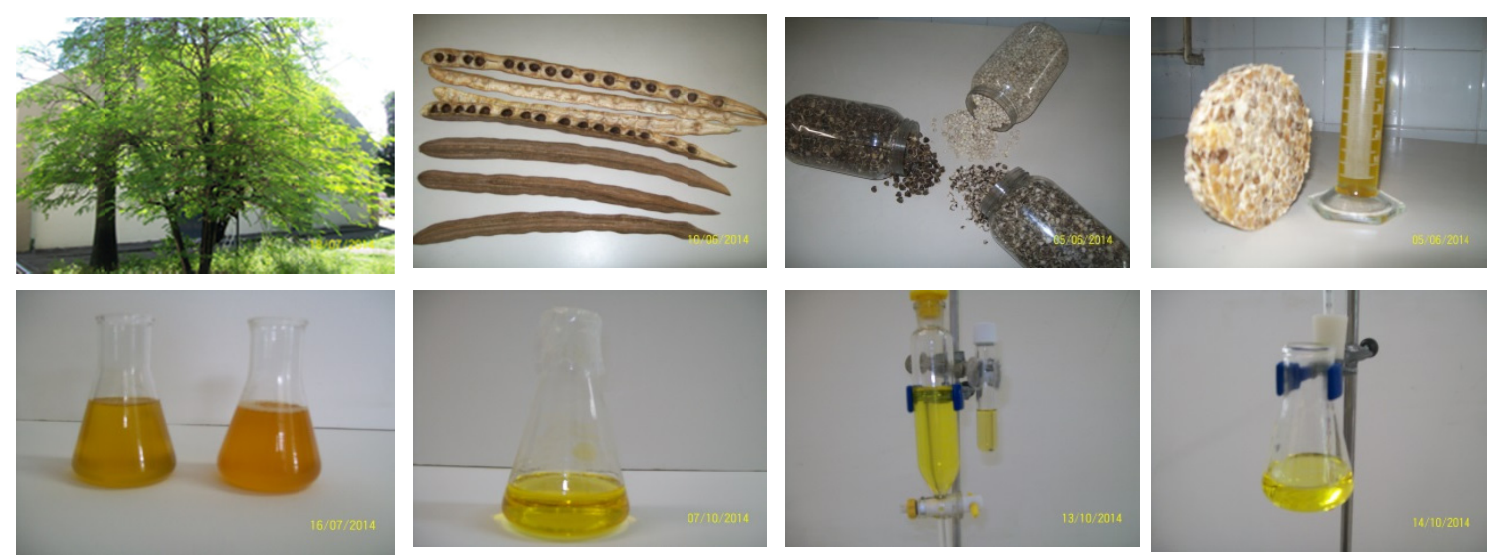

Figure 1. Plant and some biomasses obtained from moringa

(a) One of the trees used in the collection (Etepam, Encruzilhada, Recife, Brazil, 2014), (b) Seed pods opened and closed (30 to $40 \mathrm{~cm} /$ average of 16 seeds per pod), (c) Seeds, oilseed grains, and seed husks (d) Cake (or pie) and crude oil by grain pressing, (e) Oil by pressing (left) and by solvent extraction (right) (f) Mixed purified oil, (g) Impure biodiesel and glycerine (h) Purified biodiesel

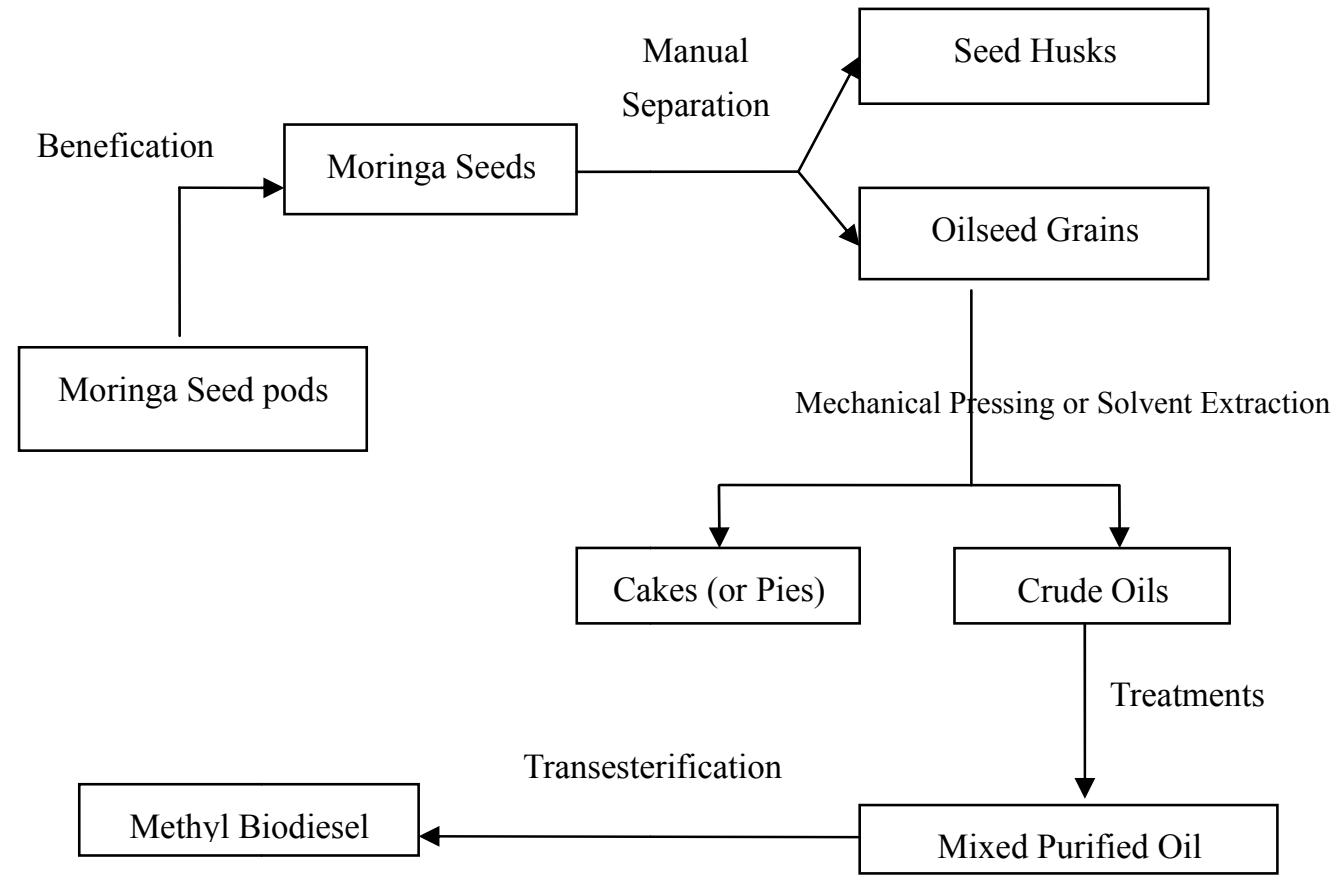

Figure 2. Scheme for the preparation of the study samples

\subsection{Physicochemical Analysis of the Moringa Oils}

Crude oils by pressing and hexane extraction and mixed purified oils were characterised by their acidity, peroxide and saponification index, and by their iodine value (Physicochemical Methods for Food Analysis of the Adolfo Lutz Institute - IAL, 2008), specific mass (NBR 14065/ASTM D4052 and NBR 7148), kinematic viscosity (NBR 10441/ASTM D445) and turbidity (turbidimeter Hach 2100N).

\subsection{Physicochemical Analysis of the Methyl Biodiesel of the Moringa Oil}

The biodiesel produced was characterised by some analytical parameters regulated by the ANP (Res. 45/2014): aspect, specific mass at $20{ }^{\circ} \mathrm{C}$ (NBR 7148), kinematic viscosity at $40{ }^{\circ} \mathrm{C}$ (NBR 10441/ ASTM D445), content of ester (EN 14103), total acidity index (NBR 9866) and content of water by Karl Fischer titration (NBR 11348/ ASTM D6304).

\subsection{Physicochemical Analysis for Energetic Purposes of the Moringa Samples}

The parameters analysed in the seeds, seed husks, oilseed grains, crude and purified oil cakes (by pressing and 
solvent extraction) were: higher calorific value (HCV, according to the operational procedure of the calorimeter IKA C 200) and lower calorific value (LCV, calculated), humidity content (Norm NBR 14660, from ABNT) or water availability (NBR 11348 of ABNT and D6304 from ASTM) and ash content (Norm NBR 9842, from ABNT).

\section{Results and Discussion}

\subsection{Physicochemical Parameters of the Moringa Oils}

The parameters chosen (Table 1) serve to evaluate the degradation or stability of the post-extraction oil, conservation or purification (acidity index, peroxide index and water content) and general characteristics of vegetable oils (specific mass, kinematic viscosity, saponification index and iodine value). The turbidity to measure possible interfering agents such as phosphatides and other colloidal products. These parameters in the oil are controlled to guarantee a good conduction in the homogenous alkaline transesterification reaction.

The acidity index (Table 1) serves to measure the presence of free fatty acids (FFA) generated by hydrolysis or by oxidative effects were considered high in crude oils and above the acceptable for biodiesel feedstock (maximum acidity of $0.5 \mathrm{mg}_{\mathrm{KOH}} / \mathrm{g}_{\text {oil }}$ ). The mixed oil used as feedstock presented $18.07 \mathrm{mg}_{\mathrm{KOH}} / \mathrm{g}_{\mathrm{oil}}$, well above the acceptable, requiring degumming, neutralisation, wash and drying treatments, efficiently modifying after the purification to $0.25 \mathrm{mg}_{\mathrm{KOH} / \mathrm{g}_{\text {oil }}}$ (mixed purified oil).

Table 1. Analytical Parameters of the investigated moringa oils

\begin{tabular}{|c|c|c|c|c|}
\hline \multirow{2}{*}{$\begin{array}{l}\text { Analytical Parameter } \\
\text { evaluated }\end{array}$} & \multicolumn{4}{|c|}{ Investigated samples } \\
\hline & $\begin{array}{c}\text { Pressed } \\
\text { oilseed grain }\end{array}$ & $\begin{array}{c}\text { Oilseed grain by } \\
\text { solvent } \\
\text { extraction }\end{array}$ & $\begin{array}{l}\text { Mixed crude } \\
\text { oil }\end{array}$ & $\begin{array}{c}\text { Mixed } \\
\text { Purified oil }\end{array}$ \\
\hline $\begin{array}{l}\text { Acidity Index(mg KOH/g oil) } \\
\text { (IAL-2008) }\end{array}$ & 8.85 & 20.54 & 18.07 & 0.25 \\
\hline $\begin{array}{l}\text { Peroxide Index }\left(\text { meq } \mathrm{O}_{2} / \mathrm{kg} \text { oil }\right) \\
\text { (IAL-2008) }\end{array}$ & 3.34 & 5.42 & 5.16 & n.d. $(* *)$ \\
\hline $\begin{array}{l}\text { Water Content(mg/kg - Karl Fischer) } \\
\text { (NBR 11348/ASTM D6304) }\end{array}$ & 876.6 & 632.0 & - & 630.2 \\
\hline $\begin{array}{l}\left.\text { Specific Mass(kg/m }{ }^{3} \text { at } 20^{\circ} \mathrm{C}\right) \\
\text { (NBR } 14065 / \mathrm{ASTM} \text { D4052) }\end{array}$ & 909.5 & 907.2 & - & $907.0(*)$ \\
\hline $\begin{array}{c}\text { Kinematic Viscosity }\left(\mathrm{mm}^{2} / \mathrm{s} \text { at } 40^{\circ} \mathrm{C}\right) \\
\text { (NBR } 10441 / \text { ASTM D445) }\end{array}$ & 43.6 & 39.1 & - & 41.7 \\
\hline $\begin{array}{c}\text { Saponification Index } \\
\text { (mg KOH/g oil)(IAL-2008) }\end{array}$ & 180.55 & 179.38 & - & - \\
\hline $\begin{array}{l}\text { Iodine value }\left(\mathrm{g} \mathrm{I}_{2} / 100 \mathrm{~g} \text { oil }\right) \\
\text { (Wijs / IAL-2008) }\end{array}$ & 68.93 & 70.71 & - & - \\
\hline $\begin{array}{l}\text { Turbidity(NTU at } 20^{\circ} \mathrm{C} \text { ) } \\
\text { (Turbidimeter Hach } 2100 \mathrm{~N} \text { ) }\end{array}$ & 64.1 & 12.6 & 31.1 & 2.1 \\
\hline
\end{tabular}

$\left.{ }^{*}\right)$ obtained by the densitometer method NBR 7148;

(**) n.d. - not detected with the applied analytical methodology.

The peroxide index is associated with the oxidation reactions in the fatty acids due to the unsaturation presence in the oil and were of 3.34, 5.42 and 5.16 meq $\mathrm{O}_{2} / \mathrm{kg}_{\text {oil }}$ (Table 1), for oils by pressing, by solvent extraction and mixed crude oil, respectively, and correspond with the high acidity indexes mentioned previously. The peroxide index of the mixed purified oil was not detected using this methodology, demonstrating that the treatments implemented removed the contaminants that cause oxidation.

The water content (Table 1) was of $876.6 \mathrm{mg} / \mathrm{kg}$ (approximately $0.09 \%$ ) for the crude oil by pressing, 632.0 $\mathrm{mg} / \mathrm{kg}$ (approximately $0.06 \%$ ) by solvent extraction and 630.2 (approximately $0.06 \%$ ) for the mixed purified oil. The results of oil by hexane extraction and of the purified oil were similar, suggesting that treatment with solvents, neutralisers and heating improve the acceptable water content in the material. The values were below the acceptable for oleaginous feedstock (maximum of $0.1 \%$ humidity) for biodiesel production (Oliveira et al., 2012).

The specific masses were of $907.2,909.5$ and $907.0 \mathrm{~kg} / \mathrm{m}^{3}\left(40{ }^{\circ} \mathrm{C}\right.$ ) (Table 1) for the oils by pressing, by solvent extraction and purified oil, respectively. The specific mass of the moringa crude or purified oil were lower than of the refined soybean oil $\left(913.8 \mathrm{~kg} / \mathrm{m}^{3}\right.$, at $\left.40{ }^{\circ} \mathrm{C}\right)$, but within the average for vegetable oils, which varied from $902.6 \mathrm{~kg} / \mathrm{m}^{3}$ for peanut to $940.6 \mathrm{~kg} / \mathrm{m}^{3}$ for babassu (Sing \& Sing, 2010).

The kinematic viscosity of the moringa crude or purified oil was higher than of the refined soybean oil (32.6 $\mathrm{mm}^{2} / \mathrm{s}$ at $40{ }^{\circ} \mathrm{C}$ ), used as the Brazilian standard reference for biodiesel production. They were of $43.6,39.1$ and 
$41.7 \mathrm{~mm}^{2} / \mathrm{s}$ (at $40{ }^{\circ} \mathrm{C}$ ) (Table 1), for crude oils by pressing and by solvent extraction and for the mixed purified oil, respectively. Sing and Sing (2010) found values between $27.2 \mathrm{~mm}^{2} / \mathrm{s}$ for linseed oil and $53.6 \mathrm{~mm}^{2} / \mathrm{s}$ for crambe oil, contemplating also $32.6 \mathrm{~mm}^{2} / \mathrm{s}$ for soybean oil, measured at $38{ }^{\circ} \mathrm{C}$; well above the $3.06 \mathrm{~mm}^{2} / \mathrm{s}$ for diesel oil at $40{ }^{\circ} \mathrm{C}$ (Garcia, 2002).

The saponification index was of $180.55 \mathrm{mg} \mathrm{KOH} / \mathrm{g}_{\text {oil }}$ for the oil by pressing and of $179.38 \mathrm{mg} \mathrm{KOH} / \mathrm{g}_{\text {oil }}$ (Table 1) by solvent extraction, both converging to the classic interval (between 180 and $200 \mathrm{mg} \mathrm{KOH} / \mathrm{g}_{\text {oil }}$ ) for saponifiable vegetable oils or animals, such as the soybean oil (with an average of $190.0 \mathrm{mg} \mathrm{KOH} / \mathrm{g}_{\text {oil }}$ ) and animal tallow (with an average of $195 \mathrm{mg} \mathrm{KOH} / \mathrm{g}_{\text {oil }}$ ) (Campestre, 2015).

The iodine value It is used to evaluate the structural characteristics in terms of the degree of unsaturation in the glycerol ester and they were of $68.93 \mathrm{gl}_{2} / 100 \mathrm{~g}_{\text {oil }}$ for the pressed oil and of $70.71 \mathrm{gl}_{2} / 100 \mathrm{~g}_{\text {oil }}$ for the oil by solvent extraction (Table 1). The soybean oil it has an iodine value between 120 and $141 \mathrm{~g} \mathrm{l}_{2} / 100 \mathrm{~g}_{\text {oil }}$ (Campestre, 2015), showing that the moringa oil can be more stable in oxidative terms. The higher this index, the higher the degree of unsaturation of the fatty material and the more vulnerable to oxidative degradation it will be.

Turbidity was used to evaluated the removal of colloids in the purification treatments of this feedstock and they were of 64.1 NTU for the pressed oil, 12.6 NTU for the crude oil by solvent extraction, 31.1 NTU for the mixed crude oil and of 2.1 NTU for the mixed purified oil (Table 1), and it shows that the chemical interactions with extraction solvents or reagents significantly reduces this parameter and prevents possible unwanted impurities in the biodiesel to be produced.

The most important parameters in the evaluation of this feedstock for biodiesel production were: the acidity index (of 18.7 for $0.25 \mathrm{mg}_{\mathrm{KOH}} / \mathrm{g}_{\mathrm{oil}}$ ), the peroxide index (of 5.16 for not detected), the water content (of 876.6 and 632.0 for $632.2 \mathrm{mg} / \mathrm{kg}$ ) and the turbidity (of 31.2 for $2.1 \mathrm{NTU}$ ), conditioned the purified oil as excellent feedstock for this purpose, resulting from the applied treatments.

\subsection{Physicochemical Parameters of the Moringa Oil Biodiesel}

The parameters investigated (Table 2) for the methyl biodiesel oil of moringa were: its aspect, specific mass, kinematic viscosity, content of ester, acidity index and water content, regulated by the resolution n.45/2014 of ANP. The specific mass and kinematic viscosity they are related to the engine performance; the acidity index the with security and stability of fuel; and the water content with the presence of impurities in fuel.

Table 2.Analytical Parameters of the methyl biodiesel and comparisons

\begin{tabular}{|c|c|c|c|c|}
\hline $\begin{array}{c}\text { Parameters/ } \\
\text { Study methods }\end{array}$ & $\begin{array}{l}\text { Data from } \\
\text { the study }\end{array}$ & $\begin{array}{l}\text { Rashid et al., } \\
(2008) / \\
\text { Rashid et al., } \\
(2011)\end{array}$ & $\begin{array}{l}\text { Oliveira et } \\
\text { al., (2012) }\end{array}$ & $\begin{array}{l}\text { Parameters to ANP } \\
\text { (Res.45/2014) }\end{array}$ \\
\hline Aspect & $\begin{array}{c}\text { Clear, } \\
\text { yellow and } \\
\text { free from } \\
\text { suspension } \\
\text { particles }\end{array}$ & - & - & $\begin{array}{c}\text { Clear and free } \\
\text { from suspension } \\
\text { particles }\end{array}$ \\
\hline $\begin{array}{c}\text { Specific mass }\left(\mathrm{kg} / \mathrm{m}^{3} / 20^{\circ} \mathrm{C}\right) \\
(\text { NBR } 7148)\end{array}$ & $869(*)$ & 875 & 887 & $850-900$ \\
\hline $\begin{array}{c}\text { Kinematic viscosity } \\
\left(\mathrm{mm}^{2} / \mathrm{s} / 40^{\circ} \mathrm{C}\right)(\mathrm{NBR} 10441)\end{array}$ & 5.5 & 4.83 & 13.56 & $3.0-6.0$ \\
\hline Content of ester (\%) & 86.2 & - & 83.68 & Min. 96.5 \\
\hline $\begin{array}{l}\text { Acidity index (mg KOH/g) } \\
\text { (NBR 14448) }\end{array}$ & 0.43 & 0.38 & 0.028 & Max. 0.50 \\
\hline $\begin{array}{l}\text { Water content }(\mathrm{mg} / \mathrm{kg}) \\
\quad(\text { ASTM D 6304) }\end{array}$ & 615.8 & 100 & $0(* *)$ & Max. 500 \\
\hline
\end{tabular}

(*) Densimeter method NBR 7148; (**) Measured as water and sediments and expressed in \%.

The specific masses of this study (Table 2) and of the bibliographic references were within the recommended range $\left(850\right.$ to $\left.900 \mathrm{~kg} / \mathrm{m}^{3}\right)$ of the resolution n. $45 / 2014$ of ANP, demonstrating that this parameter is easily reached after the oil conversion and the purification of the biodiesel produced.

The kinematic viscosity (Table 2) it was convergent with the recommended range (3.0 to $\left.6.0 \mathrm{~mm}^{2} / \mathrm{s}\right)$ of the ANP, with the exception of the Oliveira et al. (2012) study, which was of $13.56 \mathrm{~mm}^{2} / \mathrm{s}$, relatively anomalous in comparison with the other data used. This study found a $5.5 \mathrm{~mm}^{2} / \mathrm{s}$ viscosity, very close to the limit superior accepted by the ANP; but considered a product of good fluidity in the laboratory and in the sensory analysis of tact. 
The content of ester or of purity of the biodiesel (Table 2) was of $83.68 \%$ (Oliveira et al., 2012) and of $86.2 \%$ in this study. Both were lower than the recommended by the ANP (minimum of 96.5\%). A reaction of alkaline methylic transesterification with potassium hydroxide in microscale presented $98.23 \%$ of ester (purity of biodiesel), ratifying the viability of the method.

The acidity index (Table 2) of this study $\left(0.43 \mathrm{mgKOH} / \mathrm{g}_{\text {oil }}\right)$ and of the bibliographic references, 0.38 $\mathrm{mgKOH} / \mathrm{g}_{\text {oil }}$ (Rashid, Anwar, Moser, \& Knothe, 2008; Rashid, Anwar, Ashaf, Saleem, \& Yusup, 2011) and $0.028 \mathrm{mgKOH} / \mathrm{g}_{\text {oil }}$ (Oliveira et al., 2012) were converged with the recommendations of the resolution n. 45/2014 of the ANP.

The water content $(615.8 \mathrm{mg} / \mathrm{kg}$ ) found in this study (Table 2) was slightly above the limit accepted by the ANP $(500 \mathrm{mg} / \mathrm{kg})$, requiring improvements in practises in the drying phase of the biodiesel produced.

\subsection{Energetic Parameters of the Moringa Biomasses Investigated}

The parameters: humidity content, ash content, and higher (HCV) and lower calorific value (LCV) are fundamentals to the previous analysis of the use of biomass as a renewable fuel (Garcia, 2002).

The humidity and ash contents contributed negatively to the calorific value to the fuel, but are required to evaluate to its possible application and justify the energetic use of the biomass in furnaces and boilers, mainly for the production of biodiesel, in a sustainable chain (Pereira, 2007).

Garcia (2002) and Nogueira and Lora (2003) propose as acceptable parameters, that will serve as comparative data, the maximum values of $5 \%$ of ash content and of $20 \%$ of humidity content, for a direct combustion of solid biomass. Values low of these parameters can ensure a good performance the fuel. Firewood and sugarcane bagasse are greatly used in steam production and electricity generation and husks coconut are seen as of great energetic potential but still not commonly used in commercial or industrial scale (Pereira, 2009).

The solids waste fractions of the castor plant (Ricinus communis L.) are others alternatives that can be used as renewable fuels due to its combustion power. The LCV is of $22.0 \mathrm{MJ} / \mathrm{kg}$ for the gross cake (or pie), $15.6 \mathrm{MJ} / \mathrm{kg}$ for the seed husks, $16.7 \mathrm{MJ} / \mathrm{kg}$ for the stem and $16.8 \mathrm{MJ} / \mathrm{kg}$ for the root, above of the firewood $(10.8 \mathrm{MJ} / \mathrm{kg}$ ) and of the bagasse sugarcane $(8.4 \mathrm{MJ} / \mathrm{kg})$ (Pereira, 2009).

The fuels used to compare these parameters were: the air-dry firewood (average of $30.5 \%$ of humidity, $0.54 \%$ of ash content and $12.3 \mathrm{MJ} / \mathrm{kg}$ of lower calorific value), the sugarcane bagasse (50\% humidity, $11.27 \%$ of ash content and $8.4 \mathrm{MJ} / \mathrm{kg}$ of lower calorific value), the coconut husk ( $8 \%$ of humidity, $8.25 \%$ of ash content and $16.7 \mathrm{MJ} / \mathrm{kg}$ of lower calorific value), gross cake ( $8.4 \%$ humidity, $4.9 \%$ of ash content and $22.0 \mathrm{MJ} / \mathrm{kg}$ of lower calorific value) and seed husk (11.7\% humidity, $6.2 \%$ of ash content and $16.7 \mathrm{MJ} / \mathrm{kg}$ of lower calorific value) of the castor plant, respectively. The analytical results (Table 3 ) of the samples, compared with the references give a glimpse of the good perspectives for biomasses originated from the moringa.

Table 3.Results of the energetic analysis of the samples studied

\begin{tabular}{|c|c|c|c|c|c|}
\hline Sample Description & $\begin{array}{c}\text { Gravimetric } \\
\text { Humidity (\%) }\end{array}$ & $\begin{array}{l}\text { Water Content } \\
(\mathrm{mg} / \mathrm{kg})\end{array}$ & Ashes (\%) & $\begin{array}{c}\text { Higher Calorific } \\
\text { Value }(\mathrm{MJ} / \mathrm{kg})\end{array}$ & $\begin{array}{c}\text { Lower Calorific } \\
\text { Value }(\mathrm{MJ} / \mathrm{kg})\end{array}$ \\
\hline Moringa seeds & 7.34 & - & 5.61 & 22.93 & 21.14 \\
\hline Moringa seed husks & 10.86 & - & 3.86 & 18.52 & 15.87 \\
\hline Oilseed grains & 5.12 & - & 4.39 & 26.06 & 25.93 \\
\hline $\begin{array}{l}\text { Oil of grains by } \\
\text { pressing }\end{array}$ & $0.09(*)$ & 876.6 & 0.05 & 39.68 & 36.88 \\
\hline $\begin{array}{l}\text { Oil of grains by } \\
\text { solvent extraction }\end{array}$ & $0.06(*)$ & 632.0 & 0.05 & 40.03 & 36.91 \\
\hline Pressed grain cake & 6.14 & - & 4.17 & 24.81 & 23.31 \\
\hline $\begin{array}{l}\text { Cake of the grain by } \\
\text { solvent extraction }\end{array}$ & 5.83 & - & 3.96 & 19.79 & 18.49 \\
\hline Mixed purified oil & $0.06(*)$ & 630.2 & 0.007 & 39.42 & 37.13 \\
\hline Oil Methyl biodiesel & $0.06(*)$ & 615.8 & 0.01 & 39.94 & 37.53 \\
\hline
\end{tabular}

(*) Calculated based on the water content result obtained by the Karl Fischer method shown in this table.

The crude seeds are considered interesting solid biofuels due to the analytical parameters found: $7.34 \%$ of humidity, $5.61 \%$ of ashes and $21.14 \mathrm{MJ} / \mathrm{kg}$ of LCV, fitting within the parameters suggested by Garcia (2002) and Nogueira and Lora (2003) for a good renewable fuel, even better than the sugarcane bagasse, well consolidated in this field.

The seed husks also present conditions for alternative renewable fuels. The ash content (3.86\%), humidity content $(10.86 \%)$ and lower calorific value $(15.97 \mathrm{MJ} / \mathrm{kg})$ were within the tolerance range for solid biomasses. 
The ash and humidity contents were lower than those to the references and the lower calorific value was higher. However, they are considered inconvenient for this use direct, as they are composed of very light material, usually requiring the production of pellets or briquettes for density increase to improve energetic potential, and thereby, be used as an alternative renewable fuel.

The oilseed grains presented good analytical results when compared to the references, that is: humidity level of $5.12 \%$, ash content of $4.39 \%$ and lower calorific value of $25.93 \mathrm{MJ} / \mathrm{kg}$, highlighting the fact of the stored energy being twice of the air-dry firewood and three times of the sugarcane bagasse. However, their use is more adequate for oil and cake extraction.

The grain cakes (by pressing and solvent extraction) presented surprising analytical results when compared with the reference values. These cakes gather the three analytical parameters: humidity $(6.14 \%$ and $5.14 \%)$, ash content $(4.17 \%$ and $3.96 \%)$ and lower calorific value $(23.31 \mathrm{MJ} / \mathrm{kg}$ and $18.49 \mathrm{MJ} / \mathrm{kg})$ and adequate for being potentially used as renewable fuels in technological process of combustion or direct burning. The cakes can be used for this purpose alone or together with the husks of the seeds in a densification process to produce briquette or ecological firewood (Pereira, 2009).

The liquid biomasses (crude and purified oils and methyl biodiesel), easier to be used as biofuels, was also be compared with the solid reference. They present humidity content of $0.075 \%$ for both the crude and purified oils, an average ash content of $0.05 \%$ for crude and $0.004 \%$ for purified oil, much lower than the tolerance reference proposed by Garcia (2002) and Nogueira and Lora (2003). The calorific values were considered very high (36.99, 36.91 and $37.13 \mathrm{MJ} / \mathrm{kg}$ for the crude oils by pressing, by solvent extraction and the purified oil, respectively) and of $37.53 \mathrm{MJ} / \mathrm{kg}$ for the methyl biodiesel, compared with the sugarcane bagasse (50\% humidity, $11.27 \%$ of ash content and $8.4 \mathrm{MJ} / \mathrm{kg}$ of lower calorific value).

\section{Conclusions}

The Moringa oleifera Lamarck is a multifunctional plant, especially for energetic purposes, due to the good acclimatisation to Brazil and others countries, especially in the climate of the semiarid regions. The oil extracted from the oil grains and their seeds had an average yield of $11.36 \%$ by pressing and of $36.46 \%$ by hexane extraction. The moringa oil is considered an excellent feedstock for biodiesel due to its seed contents, simple extractive process and for being chemically stable to oxidation. The mixed crude oil (by pressing and by solvent extraction, 1:4 proportion) was treated by degumming, neutralisation, wash and drying and had its analytical parameters adjusted to the ones of feedstock for biodiesel production. The biodiesel oil presented purity of ester of $86.2 \%$ and $98.23 \%$ (in microscale, ratifying the viability of the method), specific mass of $869 \mathrm{~kg} / \mathrm{m}^{3}\left(20{ }^{\circ} \mathrm{C}\right)$, kinematic viscosity of $5.5 \mathrm{~mm}^{2} / \mathrm{s}\left(40{ }^{\circ} \mathrm{C}\right)$, acidity index of $0.43 \mathrm{mg} \mathrm{KOH} / \mathrm{g}$ and water content of $615.8 \mathrm{mg} / \mathrm{kg}$. The solid biomass of moringa (seeds, cakes and seed coats) presented high energetic potential (calorific value between 15.87 and $23.31 \mathrm{MJ} / \mathrm{kg}$ ) for briquette or ecological firewood production, besides the simplified technology for briquetting. All energetic applications proposed in this study are viable, highlighting the versatility of the Moringa oleifera Lamarck, mainly of its seedpods and seeds.

\section{References}

ABNT - Associação Brasileira de Normas Técnicas. (2015). Normas diversas. http://www.abnt.org.br/normalizacao/lista-de-publicacoes/abnt

ANP - Agência Nacional do Petróleo, Gás Natural e Biocombustíveis. (2015). Resolução no 45/2014. Regulamento técnico sobre a especificação do biodiesel. http://nxt.anp.gov.br/NXT/gateway.dll/leg/resolucoes_anp/2014/agosto/ranp\%2045\%20-\%202014.xml?fn= document-frameset.htm $\$ \mathrm{f}=$ templates $\$ 3.0$

BBER - Brasil Biomassa e Energia Renovável. (2015). Processo de produção de briquetes. http://abibbrasil.wix.com/brasilbiomassa\#!tipos-de-briquete/c1ggg

Bussi, J., Castigliori J., \& Tancredi, N. (2004). Biomasa como materia prima para la producción de energía, compuestos químicos y otros materiales. In: Tosti, I. (coord.): Química sustentable. Santa Fe, Argentina: Norma Nudelman.

Campestre Ind. e Com. de Óleos Vegetais Ltda. (2015). Especificações técnicas do óleo de soja e do sebo bovino. Retrieved from http://www.campestre.com.br/empresa.shtml

Crosby, G. W. (2007). Soilless culture of moringa (Moringa oleifera Lam.) for the production of fresh biomass. (Doctoral Dissertation). University of Massachusetts Amherst. http://scholarworks.umass.edu/dissertations/AAI3254941/ 
Fahey, J. W. (2005). Moringa oleifera: A Review of the Medical Evidence for Its Nutritional, Therapeutic, and Prophylactic Properties. Part 1. Trees for Life Journal, 1, 1-15. http://www.tfljournal.org/article.php/20051201124931586

Foidl, N., Makkar, H. P. S., \& Becker, K. (2001). The potential of Moringa oleifera for agricultural and industrial uses.

http://miracletrees.org/moringa-doc/the_potential_of_moringa_oleifera_for_agricultural_and_industrial_use s.pdf

Garcia, R. (2002). Combustiveis e combustão industrial, (1a. ed.), Rio de Janeiro, RJ: Interciência.

HDRA - The organic organisation. Moringa oleifera A Multi-purpose tree. $\mathrm{http} / / /$ miracletrees.org/moringa-doc/all_about_moringa_the_wonder_tree.pdf

IAL - Instituto Adolf Lutz. (2008). Métodos fisico-químicos para análise de alimentos. (4nd. ed. - 1a. ed. dig.), São Paulo, SP: Editora do IAL. http://www.crq4.org.br/sms/files/file/analisedealimentosial_2008.pdf

Nogueira, L. A. H., \& Lora, E. E. S. (2003). Dendroenergia: fundamentos e aplicações. (2nd ed.). Rio de Janeiro: Interciência.

Oliveira, D. S., Fonseca, X. D. S., Farias, P. N., Bezerra, V. S., Pinto, C. H. C., Souza, L. D., Santos, A. G. D., \& Matias, L. G. O. (2012). Obtenção do biodiesel através da transesterificação do óleo de Moringa oleifera Lam. HOLOS, 1, 49-61. http://www2.ifrn.edu.br/ojs/index.php/HOLOS/article/view/803/524

Pereira, F. S. G. (2007). Biomassa de oleaginosa como fonte alternativa de energia (Ricinus communis L.). (Dissertação de mestrado). Associação Instituto de Tecnologia de Pernambuco - ITEP. Recife, PE, Brazil. http://www.dominiopublico.gov.br/pesquisa/DetalheObraForm.do?select_action=\&co_obra $=114070$

Pereira, F. S. G., Drummond, A. R. F, \& Coimbra, G. (2009). Potencial energético de resíduos agrícolas do semiárido do Brasil. (2009). Biocombustiveis, potencialidades e restrições. BAHIA Análise \& Dados, 18, 593-602. http://www.sei.ba.gov.br/index.php?option=com_content\&view=article\&id=80\&Itemid=110

Ramos, L. P., Silva, F. R., Mangrich, A. S., \& Cordeiro, C. S. (2011). Tecnologias de Produção de Biodiesel. Revista Virtual de Química, 3, 385-405. http://dx.doi.org/10.5935/1984-6835.20110043

Rashid U., Anwar F., Moser B. R., \& Knothe G. (2008). Moringa oleifera oil: A possible source of biodiesel. Bioresource Technology, 99, 8175-8179. http://dx.doi.org/10.1016/j.biortech.2008.03.066

Rashid, U., Anwar, F., Ashraf, M., Saleem, M., \& Yusup, S. (2011). Application of response surface methodology for optimizing transesterification of Moringa oleifera oil: biodiesel production. Energy Conversion and Management, 52, 3034-3042. http://dx.doi.org/10.1016/j.enconman.2011.04.018

Singh, S. P., \& Singh, D. (2010). Biodiesel production through the use of different sources and characterization of oils and their esters as the substitute of diesel: A review. Renewable and Sustainable Energy Reviews, 14, 200-216. http://dx.doi.org/10.1016/j.rser.2009.07.017

\section{Copyrights}

Copyright for this article is retained by the author(s), with first publication rights granted to the journal.

This is an open-access article distributed under the terms and conditions of the Creative Commons Attribution license (http://creativecommons.org/licenses/by/3.0/). 